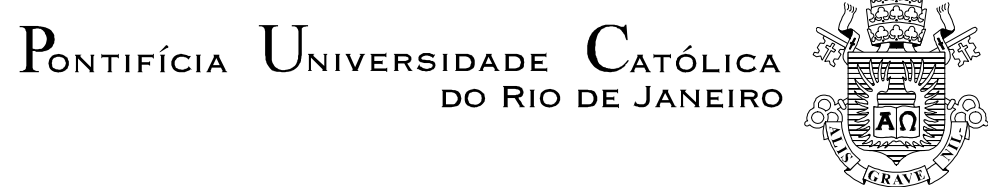

Maria Cecília Gonçalves Moreira

\title{
A Violência entre Parceiros Íntimos O Difícil Processo de Ruptura
}

Dissertação de Mestrado

Dissertação apresentada como requisito parcial para obtenção do grau de Mestre pelo Programa de Pós-graduação em Serviço Social do Departamento de Serviço Social da PUC-Rio

Orientadora: Prof ${ }^{\mathrm{a}}$. Maria Aparecida Barbosa Marques

Rio de Janeiro

Dezembro de 2005 


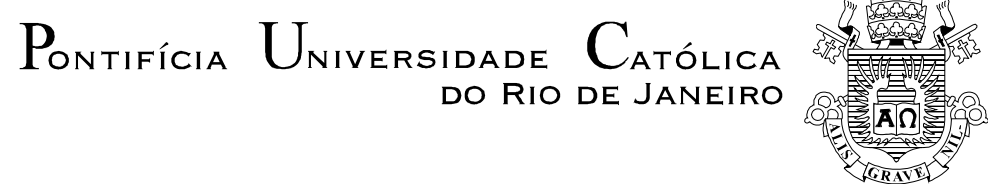

Maria Cecília Gonçalves Moreira

\section{A Violência entre Parceiros Íntimos O Difícil Processo de Ruptura}

Dissertação apresentada como requisito parcial para obtenção do grau de Mestre pelo Programa de Pós-graduação em Serviço Social do Departamento de Serviço Social da PUC - Rio. Aprovada pela Comissão Examinadora abaixo assinada.

Profa. Maria Aparecida Barbosa Marques

Orientadora

Departamento de Serviço Social - Puc-Rio

Profa. Sueli Bulhões da Silva

Departamento de Serviço Social - Puc-Rio

Prof ${ }^{a}$. Maria Euchares de Senna Motta

Departamento de Psicologia - Puc-Rio

Prof. João Pontes Nogueira

Vice-Decano de Pós-Graduação do

Centro de Ciências Sociais da PỦC-Rio

Rio de Janeiro, 15 de Dezembro de 2005. 
Todos os direitos reservados. È proibida a reprodução total ou parcial do trabalho sem autorização da universidade, da autora e da orientadora.

\section{Maria Cecília Gonçalves Moreira}

Graduou-se em Serviço Social pela UERJ (Universidade do Estadual do Rio de Janeiro) em 1973. Especialista em Docência do Ensino Superior pela UBRACE (União Brasileira de Cultura e Educação) em 2001. Especialista em Atendimento a Criança e Adolescente Vítima de Violência Doméstica pela PUC-Rio, em 2002. Participou de Congressos, Conferencias, Encontros e Seminários na área da Violencia doméstica e de Serviço Social . É assistente social da Secretaria Municipal de Assistência Social do Rio de Janeiro

Ficha Catalográfica

Moreira, Maria Cecilia Gonçalves

A violência entre parceiros íntimos: o difícil processo da ruptura / Maria Cecília Gonçalves Moreira; orientadora: Maria Aparecida Barbosa Marques. - Rio de Janeiro: PUC, Departamento de Serviço Social, 2005.

102 f.: il. ; $30 \mathrm{~cm}$

Dissertação (mestrado) - Pontifícia Universidade Católica do Rio de Janeiro, Departamento de Serviço Social.

Inclui referências bibliográficas.

1. Serviço social - Teses. 2. Violência contra a mulher. 3. Ciclo da violência. 4. Processo de ruptura. I. Marques, Maria Aparecida Barbosa. II. Pontifícia Universidade Católica do Rio de Janeiro. Departamento de Serviço Social. III. Título. 


\section{AGRADECIMENTOS}

Agradeço a Deus pela graça de superar mais um desafio.

Agradeço a minha orientadora Prof $\stackrel{a}{-}$ Maria Aparecida Marques, pelo estímulo e pela doação ao me conduzir na produção deste trabalho.

Agradeço a Profa. Sueli Bulhões pelas palavras amigas, incentivo e sensibilidade com que me acolheu num momento de ansiedade.

Agradeço as amigas do CDVida, principalmente Luciene e Maria e em especial às mulheres que se dispuseram a participar desta pesquisa.

Agradeço a todos os professores e colegas do curso de mestrado, pelos ensinamentos e pelo companheirismo.

Agradeço a minha família pela paciência e compreensão Agradeço a todos aqueles, amigas e amigos que nas horas mais difíceis se fizeram presentes, me ouvindo, me aconselhando e me fazendo crer que valia a pena prosseguir. 


\section{RESUMO}

Moreira, Maria Cecília Gonçalves. A violência entre parceiros íntimos: o difícil processo de ruptura. Rio de Janeiro. 2005. 102 p. Dissertação de Mestrado - Departamento de Serviço Social. Pontifícia Universidade Católica do Rio de Janeiro.

Realizamos o presente estudo em uma ONG que trabalha com mulheres vítimas de violência domestica, localizada no município de Duque de Caxias, o CDVida-Centro de Defesa da Vida, no período de agosto à dezembro de 2004. O nosso objetivo foi identificar na trajetória de vida dessas mulheres, os motivos que as levaram a permanecer tanto tempo em situação de violência, qual o fato que contribuiu para a quebra do silencio e em que momento elas decidiram procurar ajuda. O levantamento nos arquivos da instituição, do perfil demográfico de 60 mulheres atendidas no primeiro semestre de 2003, nos revelou o grande número de mulheres que permaneciam em situação de violência após longo período de vida em comum. Partindo desse estudo inicial, escolhemos entrevistar algumas mulheres vítimas de violência por parte de seus parceiros íntimos e que ainda se encontravam em atendimento pela equipe técnica do CDVida, objetivando entender os motivos que levaram a permanecer por tanto tempo convivendo com seus parceiros violentos. As informações colhidas nas entrevistas nos possibilitou conhecermos a percepção das mulheres em relação a violência sofrida; as conseqüências da mesma e as dificuldades enfrentadas para romper com a relação.A análise dessas informações nos levou ao entendimento de que a violência doméstica entre parceiros íntimos, é revestida de um caráter muito especial, uma vez que envolve além de laços de intimidade e afeto, na maioria dos casos, a presença dos filhos do casal, que sofrem da mesma maneira que suas mães, as conseqüências da violência. Concluímos ainda a partir dessa análise, que romper com a violência significa romper com a própria dinâmica do seu ciclo que aprisiona e paralisa a mulher. Para romper com esse ciclo, é necessário não só que a mulher encontre apoio para a superação de suas dificuldades individuais , mas também respostas institucionais para que possa exercer plenamente seus direitos enquanto cidadã.

Palavras-chave:Violência contra a Mulher; Ciclo da Violência; Processo de Ruptura. 


\section{ABSTRACT}

Moreira, Maria Cecília Gonçalves. Violence Against Intimate Partner: The difficult process of rupture. Rio de Janeiro. 2005. 102 p. Masters Dissertation - Social Work Department. Pontifícia Universidade Católica do Rio de Janeiro.

We carried out the present study in an NGO which works women, who are victims of violence in the municipality of Duque de Caxias, the CDVida - Centro de Defesa da Vida ( Center for Protection of life), from Aug to Dec 2004. Our aim was to identify the trajectory of life of these women, the reasons which led them to stay so long in situation of violence, the fact which contributed to breaking the silence, and in which moment they decided to look for help.The data found in the institution files, of a demographic profile of 60 women, trated in the first semester of 2003, revealed the great number of women who remained in situation of violence, after long living together. Starting from this initial study, we chose to interview some women, victimized by their intimate partners, and who were still under treatment by the technical team of CDVida, aiming at understanding the reasons for remaining so long, living with their violent partners. The information colleded from interviews made it possible to know the perception of the women in relation to the violence suffered: the consequences of this, and the hardships found in breaking up the relationship.The analysis of this information led us to understand that domestic violence between intimate partners is characterized in a very special manner, since it involves, besides the ties of intimacy and affection, in most cases, the presence of children of the couple, who suffer in the same way as their mothers, the consequences of violence. Furthermore, we concluded, from this analysis, that ending with violence means ending with the own dynamics of its cycle, which controls and paralyses the woman. To end up this cycle, it is necessary that the woman is not only supported to overcome her individual difficulties, but also find institutional answers in order to carry out thoroughly her rights as citizens.

Key Words: Violence against Women; Cycle of Violence; Process of Rupture 


\section{SUMÁRIO}

1. Introdução 9

2. A Condição Feminina: uma breve retrospectiva histórica 17

2.1. A condição feminina na Idade Média. 20

2.2. A condição feminina na modernidade/renascimento 25

2.3. A condição feminina na contemporaneidade 29

3. A Violência doméstica contra a mulher 41

3.1. Introduzindo o tema da violência 41

3.2. Definindo violência 45

3.3. A violência contra a mulher $\quad 47$

3.4. A violência doméstica 51

3.4.1. As formas de violência doméstica contra a mulher 52

3.4.2. As conseqüências da violência doméstica contra a mulher 53

3.4.3. O ciclo da violência doméstica 56

4. O Olhar das mulheres sobre a violência doméstica 60

4.1. Contextualizando o campo de pesquisa 60

4.1.1. O município de Duque de Caxias 60

4.1.2. O Centro de Defesa da Vida-CDVida 62

4.2. A pesquisa 64

4.3. A fala das mulheres $\quad 72$

4.3.1. A percepção sobre a violência $\quad 74$

4.3.2. As conseqüências $\quad 79$

4.3.3. O processo de ruptura 82

$\begin{array}{lr}\text { 5.Considerações Finais } & 94\end{array}$

6. Bibliografia 99 


\section{SÓ PARA MULHERES FENOMENAIS \\ (Madre Tereza de Calcutá)}

Tenha sempre presente que a pele se enruga, O cabelo embranquece, os dias convertem-se em anos...

Mas o que é importante não muda;

A tua força e convicção não tem idade.

O teu espírito é como qualquer teia de aranha. Atrás de cada linha de chegada, há uma de partida.

Atrás de cada conquista, vem um novo desafio,

Enquanto estiveres viva, sente-se viva. Se sentes saudade do que fazias, volta a fazê-lo.

Não vivas de fotografias amarelecidas...

Continua, quando todos esperam que desistas. Não deixes que enferruje o ferro que existe em ti.

Faz com que em vez de pena, te tenham respeito. Quando não consigas correr através dos anos, trota.

Quando não consigas trotar, caminha.

Quando não consigas caminhar, usa uma bengala.

Mas nunca te detenha!!! 